\title{
Komitmen Organisasi Memoderasi Pengaruh Pengendalian Intern, Kualitas Sumber Daya Manusia, dan Pemanfaatan Teknologi Informasi pada Kualitas Laporan Keuangan
}

\author{
Gusti Made Indra Satriawan*, Gusti Ayu Ketut Rencana Sari Dewi \\ Universitas Pendidikan Ganesha, Singaraja, Bali, Indonesia \\ *indrasatriawan19@gmail.com
}

\author{
Riwayat Artikel: \\ Tanggal diajukan: \\ 28 Juni 2020 \\ Tanggal diterima: \\ 28 Agustus 2020 \\ Tanggal dipublikasi: \\ 31 Agustus 2020
}

Kata kunci: Pengendalian, Sumber Daya, Teknologi, Komitmen, Laporan Keuangan

\section{Pengutipan:}

Satriawan, G. M. I., \& Dewi, G. A K. R. S. (2020). Komitmen Organisasi Memoderasi Pengaruh Pengendalian Intern, Kualitas Sumber Daya Manusia, dan Pemanfaatan Teknologi Informasi pada Kualitas Laporan Keuangan Jurnal Ilmiah Akuntansi dan Humanika, 10(2), 255-266

Keywords: Control, Resources, Technology, Commitment Financial Reports

\begin{abstract}
Abstrak
Tujuan penelitian ini adalah untuk mengkaji kembali serta membuktikan pengaruh pengendalin intern, kualitas sumber daya manusia, dan pemanfaatan teknologi informasi pada kualitas laporan keuangan dengan komitmen organisasi sebagai pemoderasi. Indikator yang digunakan untuk pengukuran adalah relevansi, keandalan, dapat dipahami dan dibandingkan. Jumlah responden sebanyak 116 yang disebarkan pada 29 Organisasi Perangkat Daerah kabupaten Buleleng dengan menentukan kriteria terhadap respondennya. Teknik analisis data menggunakan analisis regresi linear berganda dan moderated regression analysis. Hasil penelitian menunjukkan pengendalian intern dan kualitas SDM berpengaruh, sementara pemanfaatan teknologi informasi tidak beperngaruh, serta komitmen organisasi mampu memperkuat pengendalian intern, tetapi tidak mampu memperkuat kualitas SDM dan pemanfaatan teknologi informasi pada kualitas laporan keuangan.
\end{abstract}

\begin{abstract}
The aimed of this study was to review and prove the effect of the internal control, the quality of human resources, and the application of information technologhy on the quality of financial report with the organization commitment as moderating agent. The indicator used to measure were relevancy, reliability, understandibility, and comparability. The total number of the respondents were 116 that was diffused into 29 of Regional Apparatus Organization in Buleleng Regency by determining the criteria of the respondent. Analysis technique used was analisis multiple linear regression and MRA. The results were revealed internal control and the quality of human resources were effecting, while the application of information technology was not effecting, and the organization commitment could strengthen internal control, but could not strengthen the quality of human resources and the application of information technology on the quality of financial report.
\end{abstract}

\section{Pendahuluan \\ Pemerintah kini menjadi sorotan terkait dengan banyaknya tuntutan masyarakat terhadap pertanggungjawaban dan keterbukaan atas kinerja organisasi public yang berada dipusat maupun daerah. Adanya peningkatan tuntunan masyarakat ini tentang akuntabilitas dan transparansi ini diharapkan akan mendorong pihak yang bertanggungjawab khususnya dalam pengelolaan keuangan pemerintah mampu menjalankan tugas dan tanggungjawabnya dengan baik, sehingga dapat menciptakan aparatur yang tertib dan bisa menjalankan fungsinya dengan benar. Akuntabilitas dan transparansi keuangan negara adalah tujuan penting dari sektor publik (Tambingon et al., 2018).}


Berdasarkan (Peraturan Pemerintah, 2010), laporan keuangan diharuskan memenuhi kriteria : relevan, dapat dibandingkan, dapat dipahami, dan andal. Apabila pengelolaan keuangan pemerintah daerah dilakukan secara tertib dan juga bertanggungjawab, maka akan terlihat oada kualitas laporan keuangan yang dihasilkan sesuai dengan SAP dengan menggunakan anggaran yang tepat sasaran.

Untuk menilai kualitas laporan keuangan pemerintah perlu dilakukan audit dan pemeriksaan secara ketat oleh pihak yang memiliki wewenang. Opini WTP (Wajar tanpa Pengecualian) diberikan kepada pemerintah Kabupaten Buleleng yang didasarkan atas hasil pemeriksaan yang dilakukan BPK pada tahun 2019 untuk LKPD tahun 2018. Meskipun opini yang diberikan BPK kepada LKPD kabupaten Buleleng berupa opini WTP tetapi berdasarkan dari Laporan Hasil Pengawasan (LHP) semester II tahun 2017 yang diterbit pada tahun 2018 oleh perwakilan BPKP provinsi Bali, menyatakan bahwa dalam proses penyusunan laporan keuangan masih ditemukan permasalahan terkait dengan tidak patuh terhadap undangundang dan pengendalian intern dalam organisasi khususnya di kabupaten Buleleng.

Selain temuan permasalahan pada proses penyusunan LKPD, temuan lain yang didapat perwakilan BPKP Provinsi Bali yaitu, dugaan tindak pidana korupsi materiil seperti pengambil alihan aset negara dengan pensertifikatan tanah, penyelewengan pengadaan barang dan jasa, penerimaan daerah yang tidak disetor dan langsung dipergunakan serta bantuan sosial dan hibah dari pemerintah yang masih dalam tahap pemberian keterangan ahli.

Tabel 1. Pemberian Keterangan Ahli

\begin{tabular}{clcl}
\hline No & \multicolumn{1}{c}{$\begin{array}{c}\text { Lokasi Kasus } \\
\text { (Pemda) }\end{array}$} & $\begin{array}{c}\text { Jumlah } \\
\text { Kasus }\end{array}$ & \multicolumn{1}{c}{$\begin{array}{c}\text { Nilai Kerugian } \\
\text { (Rp.) }\end{array}$} \\
\hline 1 & Kab. Badung & 6 & $10.292 .069 .050,28$ \\
2 & Kab. Tabanan & 3 & $528.911 .000,00$ \\
3 & Kab. Bangli & 5 & $2.120 .979 .340,00$ \\
4 & Kab. Jembrana & 8 & $2.816 .702 .995,88$ \\
5 & Kab. Buleleng & 3 & $345.648 .861,64$ \\
6 & Kab. Badung & 13 & $44.855 .498 .047,92$ \\
7 & Provinsi & 3 & $37.940 .267 .617,00$ \\
& Jumlah & 41 & $98.900 .076 .912,72$ \\
\hline
\end{tabular}

Sumber: https://bpkp.go.id

Kerugian atas kasus dugaan tindak pidana korupsi ini mengindikasikan bahwa masih kurang efektifnya pengendalian intern di pusat pemerintahan kabupaten Buleleng sehingga masih ada celah terjadinya penyelewengan dan penyimpangan dalam pengelolaan keuangan. Jika dilihat dari jumlah kerugian setiap daerah, Kabupaten lain seperti Badung, Jembrana dan kabupaten lainnya. Buleleng merupakan kabupaten yang mengalami kerugian paling rendah, akan tetapi masuk kedalam surat edaran yang menyatakan berbagai permasalahan terkait dengan laporan keuangan pemerintah daerah, sedangkan kabupaten lain yang memiliki kerugian lebih besar tidak terdapat permasalahan tersebut sesuai dengan surat yang dikeluarkan oleh BPKP tersebut sehingga menimbulkan suatu indikasi terkait permasalahan laporan keuangan kabupaten Buleleng.

Teori stewardship menggambarkan kondisi para manajer/pegawai termotivasi akan lebih mengutamakan tujuan atau kepentingan dari organisasi/instansi tempatnya bekerja dibandingkan kepentingan dan tujuan pribadinya (Donaldson \& Davis, 1991). Demikian pula Goal-setting theory menjelaskan mengenai gambaran adanya keterkaitan/hubungan antara bagaiamana kinerja induvidu terhadapa tujuannya, dan harus bertanggungjawab atas tugastugasnya. Kinerja setiap individu tentunya akan dipengaruhi oleh seberapa besar komitmennya terhadap organisasi tempatnya bekerja dalam mencapai tujuan bersama.

Efektivitas dalam penerapan pengendalian intern di organisasi sangat diperlukan mengingat pengendalian intern memiliki peran yang signifikan dalam proses pencapaian tujuan organisasi termasuk didalamnya proses penyusunan laporan keuangan. Dalam (Peraturan Pemerintah, 2008) efektivitas pengendalian intern dapat mencegah dan mengurangi adanya risiko terjadinya ketidakakuratan ataupun kesalahan yang menyebabkan 
laporan keuangan yang dihasilkan menjadi kurang memiliki kualitas yang baik. (Herawati, 2014) berpendapat bahwa jika ingin meningkatkan kualitas laporan keuangan, pemda harus senantiasa mmbangun hubungan yang baik, dan selalu mmpertimbangkan sebelum mengalihkan dan melimpahkan tugas kepada orang lain. Kontrol yang rutin juga sangat diperlukan guna mengawasi kinerjanya.

Kontrol dalam pengelolaan keuangan dapat mengatasi pemborosan dana, sehingga diperlukan adanya evaluasi secara keseluruhan (Aditya \& Surjono, 2017). Aturan yang ketat serta kebijakan yang mengarah pada transparansi dapat diterapkan agar tidak terjadi penyimpangan. Hipotesis yang dapat diajukan sesuai dengan urain tersebut:

$\mathbf{H}_{1}$ : Pengendalian intern berpengaruh positif pada kualitas laporan keuangan.

(Gumelar, 2017) dalam proses pemilihan penyaringan pekerja haruslah dilakukan dengan dengan menetapkan kriteria sesuai dengan tempat yang diperlukan sehingga nantinya dapat memaksimalkan kemampuannya dalam bekerja.

Kualitas dari sumber daya manusia tentunya akan berpengaruh dalam proses penyusunan dan hasil yang diharapkan dari laporan keuangan tersebut. Setiap individu memilki kemampuan yang berbeda, sehingga tinggi rendahnya kompetensi setiap individu dalam bidangnya akan berpengaruh pada kinerja dan kontribusinya dalam proses penyusunan laporan keuangan. Kesalahan ataupun kekeliruan bisa saja terjadi jika SDM yang betanggungjawab dibidang tersebut kurang berkompeten sehingga tidak mampu melaksanakan tugas sesuai dengan fungsinya.

Setiap individu diharuskan untuk memiliki kemampuan yang memadai dalam bidang akuntansi guna meminimalisir terjadinya kesalahan ataupun kekeliruan dalam penyusunan laporan keuangan sesuai dengan aturan yang berlaku. Berhasil atau tidaknya sumber daya dalam menerapkan kemampuannya bergantung pada sejauh mana implementasi pengetahuan yg dimilki terhadap pekerjaanya. Jika tidak bisa menerapkan dengan baik, dapat menyebabkan kualitasnya menjadi berkurang (Soimah, 2014). Sesuai dengan urain tersebut, maka hipotesis yang diajukan:

\section{$\mathrm{H}_{2}$ : Kualitas SDM berpengaruh positif pada kualitas laporan keuangan.}

Pemanfaatan $\mathrm{TI}$ yang baik tentunya akan berdampak pada laporan keuangan yang dihasilkan, baik itu dilihat dari segi minimnya kesalahan dan kekeliruan yang terjadi. Apabila terdapat sistem yang bisa diandalkan, maka dalam proses pengolahan data (input) sampai dengan luaran informasi (output) yang dihasilkan dapat digunakan dalam pengambilan setiap keputusan secara tepat. Berdasarkan (Peraturan Pemerintah Nomor 65 Tahun 2010 Tentang Sistem Informasi Keuangan Daerah, 2010) (SIKD) bahwa dalam rangka menyelenggarakan sistem informasi akuntansi keuangan daerah yang akurat, relevan, tepat waktu, dan dapat dipertanggungjawabkan maka percepatan penyampaian informasi keuangan dalam pelaporannya diperlukan adanya teknologi yang memadai, sehingga mampu meningkatkan transparansi dan akuntabilitas.

Adanya teknologi yang semakin modern dan canggih tentunya bisa memberikan kemudahan kepada organisasi dalam mempercepat proses pertanggungjawaban dan keterbukaan mengenai laporan keuangan kepada para stakeholders. Dalam tata kelola keuangan pemerintah, semua sudah dipermudah dengan adanya teknologi berbasis digital yang diterapkan dalam menghasilkan informasi sebagai bahan dasar pertimbangan pengambilan keputusan (Widarsono, A \& Lediana, 2013). Dengan demikian, hipotesis yang diajukan adalah:

\section{$\mathrm{H}_{3}$ : Teknologi informasi berpengaruh positif pada kualitas laporan keuangan}

Dengan adanya komitmen yang tinggi terhadap organisasinya dari masing-masing individu, maka pengendalian intern akan mudah dilaksanakan atas dasar kemauan setiap individu, sehingga informasi yang berkaitan dengan keuangan pemerintah memberikan keyakinan kepada pemangku kepentingan dengan output yang dihasilkan yang tentunya berkualitas. 
Dasar pembuatan ataupun penyusunan laporan keuangan agar bisa memenuhi kriteria diperlukan adanya pengendalian yang berfungsi untuk memastikan tidak adanya kecurangan. Dengan komitmen bersama untuk membangun organisasi tentunya akan membuat setiap pegawai menaati aturan yang diterapkan dalam organisinya. Dengan kata lain, apabila komitmen organisasi dari setiap individu yang berada pada suatu entitas semakin tinggi dalam SPIP yang dilaksanakan, maka tingkat kualitas laporan keuangan yang dihasilkan tentunya akan semakin baik. Dengan demikian, hipotesis yang diajukan:

\section{$\mathrm{H}_{4}$ : Komitmen organisasi mempekuat pengaruh pengendalian intern pada kualitas laporan keuangan.}

SDM merupakan komponen yang tidak terpisahkan dengan organisasi, terlebih lagi terkait dengan seberapa besar kontribusinya nanti dalam pengeloaannya. Aapabila seorang individu berkomitmen tinggi terhadap organisasi tempatnya bekerja, maka orang tersebut akan berupaya dalam meningkatkan kualitas kerjanya dan memberikan kemampuan secara maksimal guna pencapaian tujuan organisasi tempatnya bekerja.

Edlin (2018) implementasi kemampuan setiap orang bergantung pada seberapa niatnya dalam mendidikasikan diri terhadap tempatnya bekerja. Hal ini berarti bahwa jika setiap individu yang ada pada organisasi tersebut mampu meningkatkan kapasitasnya masing-masing untuk memaksimalkan kemampuannya yang diberikan kepada organisasi tempatnya bekerja.

\section{$\mathrm{H}_{5}$ : Komitmen Organisasi memperkuat pengaruh Kualitas Sumber Daya Manusia pada kualitas laporan keuangan.}

Dengan adanya Teknologi informasi yang lebih mumpuni, diharapkan mampu memberikan kemudahan dalam berbagai proses dalam penyajian laporan keuangan, baik dari segi efisiensi waktu, tingkat keakuratan dan lain sebagainya. Ketika setiap pegawai teresbut berkomitmen pada tugasnya, maka kesadaran untuk bertanggungjawab pada instansi tersebut akan dilaksanakan Edlin (2018).

Sehingga pegawai yang berkomitmen pada organisasinya akan memberikan kemampuan dalam memanfaatkan teknologi yang ada guna kepentingan dalam proses pengolahan data dalam penyusunan laporan keuangan, agar terhindar dari adanya kesalahan input dan dapat terselesaikan dengan tepat waktu. Hal ini berarti, apabila setiap individu memiliki komitmen pada organisasinya, maka pegawai tersebut akan memanfaatkan teknologi yang ada secara maksimal sehingga mampu memberikan luaran output yang sesuai dengan harapan. Dengan demikian, hipotesis yang diajukan:

$\mathrm{H}_{6}$ : Komitmen Organisasi memperkuat pengaruh pemanfaatan $\mathrm{TI}$ pada kualitas laporan keuangan.

\section{Metode}

Jumlah populasinya yang digunakan pada penelitian ini sebanyak 29 OPD yang berada dikabupaten Buleleng. Pengambilan dan penentuan sampel dilakukan secara nonprobability sampling, yaitu dengan menggunakan pendekatan purposive sampling sesuai dengan kriteria yang sudah ditentukan sebbelumnya. Data yang dikumpulkan menggunakan metode survei dengan menyebarkan kuesioner (Sugiyono, 2017). Kusioner yang disebarkan berjumlah 116 secara langsug kepada kepala/ketua OPD, kasubah keuangan, bendahara, dan satu staff bagian keuangan pada masing-masing OPD dikabupaten Buleleng.

Skala linkert merupakan acuan yang dipergunakan dalam pengukuran atas jawaban responden ini, dan rentang skornya telah dimodifikasi menjadi angka (skor) satu sampai dengan empat dan memiliki kriteria yaitu: Skor 4: Sangat Setuju (SS), Skor 3: Setuju (S), Skor 2: Tidak Setuju (TS), dan yang terkahir Skor 1: Sangat Tidak Setuju (STS) (Kiranayanti \& Erawati, 2016). Sementara untuk teknik analisis datanya menggunakan analisis regresi linear berganda untuk pengujian hiptesis 1,2, dan 3, serta Moderated Regression Analysis (MRA) untuk hipotesis 4,5, dan 6. 


\section{Hasil dan Pembahasan}

Dalam penelitian ini, yang menjadi responden adalah pegawai ataupun pihak yang bertanggungjawab dalam pengeloaan keuangan instansi tersebut. Kuisioner yang telah disebar sebanyak 116 dengan tingkat pengembalian sebesar $86 \%$ atau sebanyak 100 kusioner, 8 kusioner tidak kembali, dan 8 kusioner lainnya ditolak terkait pandemi COVID-19, sehingga data kusioner yang dapat digunakan sebanyak 100 kusioner dari keseluruhan kusioner yang telah disebar.

Untuk menjelaskan data yang diperoleh dari keseluruhan varibel yang telah digunakan dalam penelitian yang dilihat dari jumlah data, rentang, nilaii minimum (terrendah), nilai maksimum (tertinggi), rata-rata (mean), dan standar deviasi.

Tabel 2. Hasil Uji Statistik Deskriptif

\begin{tabular}{lcccccc}
\hline Variabel & $\begin{array}{c}\text { Jumlah } \\
\text { Data }\end{array}$ & Rentang & $\begin{array}{c}\text { Nilai } \\
\text { Minimum }\end{array}$ & $\begin{array}{c}\text { Nilai } \\
\text { Maksimum }\end{array}$ & $\begin{array}{c}\text { Rata-rata } \\
\text { (mean) }\end{array}$ & $\begin{array}{c}\text { Std. } \\
\text { Deviation }\end{array}$ \\
\hline PI & 100 & 14.00 & 26.00 & 40.00 & 32.3500 & 3.32233 \\
KSDM & 100 & 17.00 & 27.00 & 44.00 & 34.7200 & 3.29395 \\
PTI & 100 & 8.00 & 16.00 & 24.00 & 20.4300 & 2.34523 \\
KO & 100 & 12.00 & 20.00 & 32.00 & 24.4600 & 3.11211 \\
KLK & 100 & 12.00 & 32.00 & 44.00 & 36.8100 & 3.40735 \\
\hline
\end{tabular}

(Sumber: Data diolah, 2020)

Dalam penelitian ini, sebelum menguji pengaruh variabel yang diteliti, terdapat prasyaratan yang harus dipenuhi dalam analisis statistik parametrik dan analisis regresi yaitu uji normalitas, multikolonieritas, dan heteroskedastisitas.

Tabel 3. Uji Asumsi Klasik.

\begin{tabular}{|c|c|c|c|}
\hline No & Uji Asumsi Klasik & Nilai & Hasil \\
\hline \multirow[t]{3}{*}{1} & Uji Normalitas & & \multirow{3}{*}{$\begin{array}{l}\text { Nilai Test Statistic dan nilai } \\
\text { Monte Carlo Sig. (2-tailed) > } \\
0,05 \text {. Dapat dinyatakan } \\
\text { residual berdistribusi normal }\end{array}$} \\
\hline & \multirow{2}{*}{$\begin{array}{l}\text { Test Statistic } \\
\text { Monte Carlo Sig. (2-tailed) }\end{array}$} & 0.70 & \\
\hline & & 0.696 & \\
\hline \multirow[t]{11}{*}{2} & Uji Multikolonieritas & & \multirow{11}{*}{$\begin{array}{l}\text { Dapat dinyatakan tidak } \\
\text { terdapat multikolinieritas. } \\
\text { Karena nilai Tolerance } \\
\text { semua diatas } 0,10 \text { dan nilai } \\
\text { VIF semua dibawah } 10 .\end{array}$} \\
\hline & Tolerance & & \\
\hline & $\mathrm{PI}$ & 0.508 & \\
\hline & KSDM & 0.751 & \\
\hline & PTI & 0.768 & \\
\hline & $\mathrm{KO}$ & 0.516 & \\
\hline & \multicolumn{2}{|l|}{ VIF } & \\
\hline & PI & 1.967 & \\
\hline & KSDM & 1.331 & \\
\hline & PTI & 1.303 & \\
\hline & $\mathrm{KO}$ & 1.939 & \\
\hline \multirow[t]{6}{*}{3} & Uji Heteroskedastisitas & & \\
\hline & Variabel & Sig & Keterangan \\
\hline & Pengendalian Intern $\left(\mathrm{X}_{1}\right)$ & 0.713 & \multirow{4}{*}{$\begin{array}{l}\text { Tidak ada gejala } \\
\text { heteroskedastisitas karena } \\
\text { semua memenuhi } \\
\text { persyaratan dengan nilai } \\
\text { Sig. diatas } 0,05 \text {. }\end{array}$} \\
\hline & Kualitas SDM $\left(\mathrm{X}_{2}\right)$ & 0.070 & \\
\hline & Pemanfaatan Teknologi Informasi $\left(\mathrm{X}_{3}\right)$ & 0.642 & \\
\hline & Komitmen Organisasi $\left(\mathrm{X}_{4}\right)$ & 0.254 & \\
\hline
\end{tabular}

(Sumber: Data diolah, 2020) 
Nilai konstanta dan koefisien regresinya ditunjukkan pada tabel 4, nilai tersebut digunakan untuk membuat persamaan berikut:

$Y=7,554+0,669 X 1+0,176 X 2+0,073 X 3+e$

Konstansta ( $\alpha$ ) 7,554 memiliki arti bahwa, apabila nilai dari variabel pengendalian intern, kualitas sumber daya manusia, pemanfaatan teknologi informasi, dan komitmen organisasi adalah sama dengan nol (0), maka kualitas laporan keuangan meningkat sebesar 7,554. Koefisien regresi pengendalian itern adalah sebesar 0,669 yang berarti jika terjadi peningkatan sebesar satu satuan, sementara variabel independen/bebas lainnya diasumsikan sama dengan nol (0), maka kualitas laporan keuangan akan meningkat sebesar 0,669. Koefisien regresi kualitas sumber daya manusia adalah sebesar 0,176 yang berarti jika terjadi peningkatan sebesar satu satuan, sementara variabel independen/bebas lainnya diasumsikan sama dengan nol (0), maka kualitas laporan keuangan akan meningkat sebesar 0,176. Koefisien regresi pemanfaatan teknologi informasi adalah sebesar 0,073 yang berarti jika terjadi peningkatan sebesar satu satuan, sementara variabel independen/bebas lainnya diasumsikan sama dengan nol (0), maka kualitas laporan keuangan akan meningkat sebesar 0,073 .

Tabel 4 Analisis Regresi Linear Berganda

\begin{tabular}{lcrccc}
\hline \multirow{2}{*}{ Model } & \multicolumn{2}{c}{$\begin{array}{c}\text { Unstandardized } \\
\text { Coefficients }\end{array}$} & $\begin{array}{c}\text { Standardized } \\
\text { Coefficients }\end{array}$ & \\
\cline { 2 - 6 } & $\mathrm{B}$ & Std. Error & Beta & $\mathrm{t}$ & Sig \\
\hline (Konstanta) & 7.554 & 3.011 & & 2.509 & 0.014 \\
Pengendalian Intern $\left(\mathrm{X}_{1}\right)$ & 0.669 & 0.075 & 0.652 & 8.951 & 0.000 \\
Kualitas S D M $\left(\mathrm{X}_{2}\right)$ & 0.176 & 0.081 & 0.170 & 2.173 & 0.032 \\
Pemanfaatan Teknologi & 0.073 & 0.112 & 0.050 & 0.653 & 0.515 \\
Informasi $\left(\mathrm{X}_{3}\right)$ & & 0.541 & & & \\
Adjusted $R$ square & & & & &
\end{tabular}

(Sumber: Data diolah, 2020)

Nilai koefisien determinasi didapat dari nilai Adjusted R Square yaitu sebesar 0,541. Transformasi nilainya menjadi $54,1 \%$ dengan artian bahwa variabel kualitas laporan keuangan ini bisa dijelaskan oleh ketiga variabel bebasnya yaitu: pengendalian intern, kualitas sumber daya manusia dan pemanfaatan teknologi informasi, dan sebesar 45,9\% (100\% - 54,1\%) dijelaskan oleh kemungkinan lainnya. Dengan persentase sebesar itu, bisa dikatakan sudah cukup, meskipun masih ada 45,9\% bisa dijelaskan dengan instrumen lainnya.

Tabel 5. Moderated Regression Analysis

\begin{tabular}{|c|c|c|c|c|}
\hline Model & (Konstanta) & $\begin{array}{c}\begin{array}{c}\text { Unstandardized } \\
\text { Coefficients }\end{array} \\
\text { B }\end{array}$ & Sig & $\begin{array}{c}\text { Adjusted } R \\
\text { square }\end{array}$ \\
\hline$\left(X_{1}\right)^{* *}$ & & -0.711 & 0.193 & \\
\hline$\left(X_{4}\right)^{* *}$ & 47.574 & -0.895 & 0.209 & 0.656 \\
\hline Interaksi $\mathrm{X}_{1} \mathrm{X}_{4}$ & & 0.043 & 0.043 & \\
\hline$\left(\mathrm{X}_{2}\right)^{\star *}$ & & 0.383 & 0.447 & \\
\hline$\left(X_{4}\right)^{* *}$ & 4.594 & 1.009 & 0.156 & 0.603 \\
\hline Interaksi $\mathrm{X}_{2} \mathrm{X}_{4}$ & & -0.007 & 0.731 & \\
\hline$\left(X_{3}\right)^{\star *}$ & & 0.023 & 0.977 & \\
\hline$\left(X_{4}\right)^{* *}$ & 16.791 & 0.700 & 0.307 & 0.572 \\
\hline Interaksi $\mathrm{X}_{3} \mathrm{X}_{4}$ & & 0.005 & 0.883 & \\
\hline
\end{tabular}

** : Uji persamaan setelah adanya interaksi

(Sumber: Data diolah, 2020) 
Tabel 6. Uji Pengaruh Parsial

\begin{tabular}{lcccc}
\hline \multicolumn{1}{c}{ Variabel } & Nilai Sig. & $\boldsymbol{\alpha}$ & \multicolumn{2}{c}{ Kesimpulan } \\
\hline PI & 0.000 & & $0.000<0.05$ & Signifikan \\
KSDM & 0.032 & & $0.032<0.05$ & Signifikan \\
PTI & 0.515 & & $0.515>0.05$ & Tidak \\
Moderasi PI*KO & 0.043 & 0.05 & $0.043<0.05$ & Signifikan \\
Moderasi KSDM ${ }^{*} \mathrm{KO}$ & 0.731 & & $0.731>0.05$ & Tdak \\
Moderasi PTI*KO & 0.883 & & $0.883>0.05$ & Tidak \\
\hline
\end{tabular}

(Sumber: Data diolah,2020)

\section{Pembahasan 1}

Pengaruh Pengendalian Intern pada Kualitas Laporan Keuangan Nilai Sig. variabel PI yaitu $0,000<0,05$, berarti, berarti signifikan atau hipotesis pertama $\left(\mathrm{H}_{1}\right)$ diterima. Hasil yang sama didapatkan oleh penelitian yang dilakukan, (Sudiarianti, N. M., Ulupui, I. G. K. A., \& Budiasih, 2015), (Trisnawati, N. N., \& Wiratmaja, 2018),

Laporan keuangan yang berkualitas yang dihasilkan oleh pemda salah satunya dapat dipengaruhi oleh seberapa efektif penerapan pengendalian intern dalam suatu entitas. Kinerja pemerintah dalam proses penyusunan laporan keuangan diawasi melalui pengendalian intern agar terhindar dari adanya suatu indikasi kecurangan yang mungkin akan dilakukan oleh pihak yang ingin mendapatkan keuntungan pribadi ataupun kelompok sehingga dapat merugikan masyarakat dan juga negara. Secara konseptual, jika penerapan pengendalian intern dapat diterapkan secara efektif, maka akan berpengaruh pada naiknya kualitas output keuangan, begitu juga sebaliknya, laporan keuangan akan semakin menurun kualitasnya jika pengendalian yang diterpkan tidak mampu berjalan dengan baik.

Penelitian ini memperoleh hasil bahwa pengendalian intern berpengaruh positif dan signifikan pada kualitas laporan keuangan, sehingga penelitian ini mendukung teori stewardship. Pemerintah sebagai berkewajiban dalam memberikan pertanggungjawaban kepada masyarakat terkait dengan informasi pengeloaan keuangan. Salah satu cara dalam menjalankan bentuk pertanggungjawaban tersebut adalah dengan peningkatan pengelolaan keuangan, kinerja secara menyeluruh dari setiap divisi, serta menerapkan pengendalian intern yang memadai dan efektif diterapkan pada pemerintah kabupaten Buleleng.

Setiap organisasi tentunya memiliki sistem pengendalian yang berbeda sesuai dengan kebutuhan dan tujuan dari organisasi tersebut. Pengukuran kinerja pegawai instansi juga dapat dilihat dari seberapa dipatuhinya aturan ataupun kebijakan yang telah dibuat oleh manajemen, karena hal tersebut berkaitan dengan pengelolaan sumber daya yang ada, sehingga dapat mendorong adanya efisensi dalam kegiatan operasional pemerintah. Baiknya pengendalian yang dilakukan oleh pemerintah kabupaten Buleleng dapat mengurangi tindak kecuarangan yang mungkin dilakukan oleh pihak yang memiliki kepentingan pribadi. Pengendalian ini dilakukan guna memaksimalkan berbagai informasi mengenai keuangan pemerintah dapat dipertanggungjawabkan sehingga masyrakat percaya dengan kinerja pemerintah.

\section{Pembahasan 2}

Nilai Sig. variabel KSDM yaitu 0,032 <0,05, berarti, berarti signifikan atau hipotesis kedua (H2) diterima. Hasil penelitian yang sama juga diperoleh (Kiranayanti \& Erawati, 2016), (Agung, T. M., 2018), (Suarmika \& Suputra, 2016).

Dengan adanya sumber daya manusia baik individu maupun kelompok merupakan salah satu elemen yang pasti ada dan memiliki peran paling penting dari suatu organisasi didalamnya yang diharapkan mampu memberikan kontribusi yang maksimal dengan kemampuan yang dimiliki terhadap tujuan organisasi. Dengan adanya individu yang memeiliki kompetensi dibidangnya, tentu akan mampu meberikan kontribusi secara optimal dalam penyusunan laporan keuangan yang berkualitas berdasarkan standar akuntansi yaitu SAP.

Ketika sumber daya tersebut memiliki pengalaman lebih dibidangnya, maka akan sangat mudah dan lebih cepat dalam menyelesaikan setiap pekerjaannya, karena telah 
memahami tugas yang akan dikerjakan, sehingga mampu menghasilakan laporan yang baik, tepat waktu dalam penyelesaian, serta mengurangi tingkat kesalahan dalam pencatatan akuntansinya. Pada umumnya, semakin berkualitas sumber daya yang dimilki oleh pemda kabupaten Buleleng, maka laporan yang dihasilkan tentunya semakin memiliki kualitas yang bagus, dan sebaliknya, apabila kualias sumber daya yang dimiliki kurang memadai, maka kualitas laporan keuangan pemerintah daerah akan menurun.

Penelitian ini memperoleh hasil bahwa kualitas SDM berpengaruh positif dan signifikan pada kualitas laporan keuangan, sehingga penelitian ini mendukung teori stewardship. Sebagai bentuk pertanggungjawaban pemerintah (steward) kepada rakyat, diperlukan adanya SDM yang berkompeten (Wati, K. D., Herawati, N. T., \& Sinarwati, 2014) SDM yang memiliki kompetensi yang cukup, akan siap bertanggungjawab dengan laporan keuangan yang telah dihasilkan sesuai dengan aturan. Ditambah lagi dengan kualitas sumber daya yang mendasari setiap individu mencapai kinerja yang tinggi.

Sebagai salah satu kunci berjalannya suatu instansi yang bertugas sebagai penggerak organiasasi, kualitas sumber daya diharapkan memiliki kemampuan yang memadai. Kemampuan individu setiap pegawai memungkinkan peningkatan kualitas output yang dihasilkan. Penempatan posisi atas tanggungjawab yang diberikan akan berpengaruh pada kinerjanya, ketika kemampuan yang dimilikinya tidak sesuai dengan posisi/jabatan tempatnya bekerja, maka akan berdampak pada kurang maksimalnya kontribusi yang akan diberikan karena keterbatasan penguasaan bidang tersebut. Dalam proses rekrutmen dirasa sangat baik dilakukan oleh pemerintah kabupaten Buleleng, dapat ditunjukkan dari hasil kinerja dan pertanggungjawabnya dalam menghasilkan laporan keuangan yang memiliki kualitas. Pelatihan dan pengembangan pegawai juga diperlukan guna mengikuti perkembangan teknologi yang digunakan dalam pengelolaan keuangan pemerintah. Berhasil atau tidaknya organisasi dalam melaksanakan tanggungjawabnya pada masyarakat tergantung pada kualitas individu pegawai tersebut.

\section{Pembahsan 3}

Nilai Sig. variabel PTI yaitu 0,515 $>0,05$, berarti, berarti signifikan atau dengan kata lain hipotesis yang ketiga $(\mathrm{H} 3)$ ditolak dan $(\mathrm{HO})$ diterima. Hasil yang sama diperoleh Ningrum (2018), Setyowati dkk (2016), Riandani (2017) Harnoni (2016)

Berdasarkan PP No. 65 Tahun 2010 tentang Sistem Informasi Keuangan Daerah (SIKD), dengan adanya teknologi informasi yang mumpuni, seharusnya dapat dimanfaatkan secara maksimal untuk meningkatkan kualitas pengelolaan keuangan pemerintah serta mempermudah menyalurkan informasi kepada pihak yang berkepentingan. Umumnya, ketika teknologi yang ada di OPD kabupaten Buleleng semakin canggih ditambah dengan pemanfaatan yang maksimal, maka laporan keuangan seharusnya semakin baik, akurat, dan minim dari adanya kesalahan.

Teori stewardship menjelaskan bahwa untuk menghasilkan laporan keuangan yang berkualitas, diperlukan adanya pemanfaatan teknologi informasi yang efektif dan efisien dan bisa diterapkan dalam pembuatan laporan keuangan pemerintah kabuapten Buleleng. Akan tetapi, penelitian ini menunjukkan hasil bahwa variabel pemanfaatan teknologi infromasi tidak berpengaruh pada kualitas laporan keuangan di kabupaten Buleleng.

Hasil ini tentu saja dirasa sangat bertentangan dengan kenyataannya jika dilihat secara umum, mengingat teknologi informasi merupakan alat utama dalam proses pengeloalaan data yang digunakan oleh pegawai dalam penyusunan laporan. Namun hal tersebut mungkin saja disebabkan oleh berbagai faktor seperti kerusakan ataupun gangguan jaringan yang menghambat dalam proses penyusunan laporan keuangan di OPD kabupaten Buleleng, sehingga fungsi yang harusnya dijalankan tidak dapat digunakan secara maksimal dalam menghasilkan output laporan keuangan yang baik. Kendala yang dialami tersebut akan berdampak pada seberapa lama laporan keuangan dapat terselesaikan. Selain karena faktor sorftware ataupun hardware, faktor lain seperti kemampuan sumber daya dalam mengaplikasikan teknologi juga dianggap berpengaruh terkait dengan penyesuaian tingkat perkembangan teknologi dan kemampuan adaptasinya. 


\section{Pembahasan 4}

Nilai Sig. interaksi PI dan KO yaitu 0,043 $<0,05$, berarti, berarti signifikan atau hipotesis pertama ( $\mathrm{H} 4)$ diterima. Hasil penelitian yang sama juga diperoleh Alminanda dan Marfuah (2018), dan Sanjaya (2017), Mulyadi dkk (2019).

Pada umumnya, ketika setiap individu mampu berkomitmen tinggi pada tujuan oganisasi tempatnya bekerja, hal itu bisa memberikan dampak positif pada tindakan dan kualitas dari kinerjanya, sehingga dapat memberikan kontribusi kemampuan yang maksimal untuk OPD kabupaten Buleleng yaitu mampu meningkatkan pengendalian intern pemerintah sehingga dapat memberikan suatu keyakinan kepada masyarakat terhadap seberarap handal laporan yang dihasilkan.

Dalam penelitian ini hasil yang diperoleh adalah komitmen organisasi di OPD kabupaten Buleleng mampu memperkuat pengaruh pengendalian intern pada kualitas laporan keuangan kabupaten Buleleng, sehingga penelitian ini mendukung teori stewardship dan teori kontinjensi. Pemerintah sebagai steward berkewajiban untuk memberikan pertanggungjawaban kepada masyarakat terkait dengan informasi pengeloaan keuangan. Demikian pula teori kontinjensi meyatakan bahwa seseorang yang mampu memahami dan memiliki komitmen yang tinggi dalam mencapai tujuan, maka pemahaman tersebut akan mempengaruhi perilaku kerjanya.

Dengan adanya komitmen organisasi yang baik pada OPD kabupaten Buleleng dalam membentuk pengendalian intern akan berdampak pada kinerja anggota organisasinya. Setiap individu yang berkomitmen tinggi akan berusaha untuk memtahuhi berbagai aturan yang diterapkan, sehingga akan mampu memaksimalkan kinerja setiap pegawai dalam menghasilkan laporan keuangan yang memiliki kualitas.

\section{Pembahasan 5}

Nilai Sig. interaksi PI dan KO yaitu 0,731 <0,05, berarti, berarti signifikan atau hipotesis pertama (H5) diterima. Penelitian ini memeproleh hasil yang sama dengan Andrianto (2017), Alminanda dan Marfuah (2018), Siwambudi, Yasa, dan Badera (2017), Wulandari (2018).

Hubungan yang erat antara individu dengan organisasi tempatnya bekerja merupakan implementasi adanya komitmen yang tinggi terhadap instansi tersebut. Apabila pegawai memilliki komitmen yang tinggi pada organisasi tempatnya bekerja sesuai dengan tujuan organisasinya, maka akan memberikan dampak positif pada tindakan dan kualitas dari kinerjanya, sehingga dapat memberikan kontribusi kemampuan yang maksimal untuk OPD kabupaten Buleleng.

Teori stewardship menyatakan bahwa sebagai bentuk pertanggungjawab pemerintah kepada masyarakat, maka laporan keuangan yang dihasilkan harus berkualitas, sehingga diperlukan adanya SDM yang berkompeten. Demikian pula teori kontinjensi meyatakan bahwa ketika sertiap individu yang berada pada organisasi punya komitmen yang tinggi, mka hal tersebut akan beperngaruh pada perilaku kerjanya dan akan memberikan kemampuan secara maksimal terhadap organisasi tempatnya bekerja. Hasil yang didapat dalam penelitian ini menyatakan bahwa komitmen organisasi tidak bisa memperkuat pengendalian dalam pengaruhnya pada kualitas laporan keuangan OPD dikabupaten Buleleng, oleh karena itu, penelitian ini tidak dapat mendukung teori yang dipakai yaitu stewardship dan kontinjensi.

$\mathrm{Hal}$ itu kemungkinan disebabkan oleh adanya ketidaknyamanan pegawai akibat tekanan berlebih dari atasan, sehingga kemampuan dari setiap individu tidak dapat dikeluarkan secara maksimal, apalagi ditambah dengan fasilitas yang kurang memadai, minimnya pemberian penghargaan (reward) terhadap pegawai memiliki prestasi, ketidaksesuaian upah atas pekerjaan yang dilakukan, ataupun kurangnya promosi jabatan. Namun kondisi ini disikapi oleh pegawai OPD kabupaten Buleleng dengan menunjukkan komitmen kepada organisasi karena loyalitas terhadap OPD tempatnya bekerja. Sejalan dengan pendapat Wijayanti (2008), pegawai bisa saja merasa tidak puas dengan pekerjaanya, akan tetapi memilih tetap terus berkomitmen terhadap organisasinya. 


\section{Pembahasan 6}

Nilai Sig. interaksi PI dan KO yaitu 0,731 <0,05, berarti, berarti signifikan atau hipotesis pertama $\left(\mathrm{H}_{6}\right)$ ditolak. Hasil penelitian sama juga diperoleh Andrianto (2017), Siregar (2017), dan Arief (2016).

Kemampuan setiap individu berbeda-beda dalam mengoperasikan sistem yang ada pada organisasi. Sehingga diperlukan orang yang memang ahli pada bidang ini. Begitu juga dengan teknologi yang ada harus dapat mendukung dalam proses pengerjaanya sehingga bisa menghasilkan output yang cepat dan akurat.

Teori stewardship mejelaskan bahwa untuk menghasilkan laporan keuangan yang berkualitas, diperlukan adanya pemanfaatan teknologi informasi yang bisa mempermudah, mempercepat, dan akurat dalam penyusunan laporan keuangan. Demikian pula teori kontinjensi meyatakan bahwa seseorang yang memiliki komitmen yang tinggi dalam mencapai tujuan, maka hal tersebut akan mempengaruhi perilaku kerjanya dan akan memberikan kemampuan secara maksimal dalam memanfaatkan teknologi informasi yang telah ada secara maksimal terhadap organisasi tempatnya bekerja.

Namun penelitian ini mendapatkan hasil bahwa komitmen organisasi tidak dapat memperkuat pengaruh pemanfaatan teknologi informasi pada kualitas laporan keuangan OPD kabupaten Buleleng, dan tidak dapat mendukung teori stewardship dan teori kontinjensi. Hal ini dirasa wajar karena teknologi dengan komitmen memiliki konteks yang berbeda. Teknologi merupakan alat ataupun sistem yang menjalankan suatu proses pengelolaan, sedangkan komitmen berkaitan dengan keinginan masing-masing individu sehingga ada ataupun tidaknya komitmen organisasi tidak akan berdampak pada teknologi informasi pada OPD kabupaten Buleleng.

Bagaimanapun canggihnya teknologi yang ada pada instansi tersebut, apabila orang yang mengoperasikannya tidak memiliki kemampuan yang cukup, maka hal tersebut berdampak pada kurang maksimalnya output yang dihasilkan, berbeda dengan orang yang memang ahli dalam teknologi pasti dapat mengelola dengan baik. Sehingga kaitan antara komitmen dengan teknologi bergantung pada individunya masing-masing, jika dilihat dari pembahasan ke 5, sudah terlihat juga bahwa sumber dayanya pun kurang memiliki komitmen dalam menjalankan organisasinya.

\section{Simpulan dan Saran}

Berdasarkan hasil penelitian yang telah dibahas sebelumnya dapat disimpulkan bahwa (Sesuai ddengan pembahasan yang telah dipaparkan diatas, peneliti dapat menyimpulkan hasil secara ringkas yaitu: Pengendalian intern (PI) dan kualitas SDM (KSDM) memiliki pengaruh, sedangkan pemanfaaran teknologi informasi (PTI) tidak berpengaruh pada kualitas laporna keuangan. Komitmen organisasi memperkuat pengaruh PI akan tetapi tidak bisa memperkuat KSDM dan PTI pada lkualitas laporan keuangan. Peneliti selanjutnya disarankan untuk menimbang kembali pengambilan variabel sesuai dengan teori stewardship, teori kontinjensi ataupun teori yang lainnya. Nilai dari Adjusted $R$ square $\left(R_{2}\right)$ sebesar 0,541 , atau koefesien regresinya sebesar $54,1 \%$ yang berarti sebesar itu variabel yang digunakan peneliti bisa menjelaskan variasinya.

Adapun saran yang dapat disampaikan bagi penelitian berikutnya disarankan menggunakan faktor lain yang bisa berpengaruh serta memperluas ruang lingkup penelitian sehingga memungkinkan adanya hasil yang berbeda..

\section{Daftar Rujukan}

Aditya, O. R., \& Surjono, W. (2017). Pengaruh Sistem Pengendalian Intern Terhadap Kualitas Laporan Keuangan. Jurnal SIKAP (Sistem Informasi, Keuangan, Auditing Dan Perpajakan) Universitas Sanggar Buana, Vol 2 No 1, Hal 49-62. https://doi.org/10.32897/sikap.v2i1.64

Agung, T. M., \&. G. (2018). Analisis Faktor-Faktor yang Mempengaruhi Kualitas Laporan Keuangan Pemerintah Daerah Kabupaten Karangasem. E-Jurnal Akuntansi, Vol 23 No 
2, Hal 1253-1276.

Donaldson, L., \& Davis, J. H. (1991). Stewardship Theory or Agency Theory: CEO Governance and Shareholder Returns. Australian Journal of Management, Vol 16 No, Hal 49-64. https://doi.org/10.1177/031289629101600103

Gumelar, A. (2017). Pengaruh Kualitas Sumber Daya Manusia, Penerapan Standar Akuntansi Pemerintahan dan Sistem Pengendalian Intern terhadap Kualitas Laporan Keuangan Pemerintah Daerah (Studi Empiris pada SKPD Kabupaten Kerinci). E-Journal Akuntansi Universitas Negeri Padang, Vol 5, No 2.

Herawati, N. T. (2014). Pengaruh Sistem Pengendalian Intern Terhadap Kualitas Laporan Keuangan (Survei Pada Organisasi Perangkat Daerah Pemda Cianjur). Study and Accounting Research Bandung Business School, Vol XI No 1.

Kiranayanti, I., \& Erawati, N. (2016). Pengaruh Sumber Daya Manusia, Sistem Pengendalian Intern, Pemahaman Basis Akrual Terhadap Kualitas Laporan Keuangan Daerah. E-Jurnal Akuntansi, Vol 16, No, Hal 1290-1318.

Peraturan Pemerintah. (2008). PERATURAN PEMERINTAH REPUBLIK INDONESIA NOMOR 60 TAHUN 2008 TENTANG SISTEM PENGENDALIAN INTERN PEMERINTAH. Pp. https://doi.org/10.1016/j.cell.2009.01.043

Peraturan Pemerintah Nomor 65 Tahun 2010 Tentang Sistem Informasi Keuangan Daerah, (2010).

Peraturan Pemerintah. (2010). PERATURAN PEMERINTAH REPUBLIK INDONESIA NOMOR 71 TAHUN 2010 TENTANG STANDAR AKUNTANSI PEMERINTAHAN. Pp. https://doi.org/10.1093/occmed/kqq062

Soimah, S. (2014). Pengaruh Kapasitas Sumber daya Manusia, Pemanfaatan Teknologi Informasi dan Sistem Pengendalian Intern Pemerintah Terhadap Kualitas Laporan Keuangan Pemerintah Daerah Kabupaten Bengkulu Utara. Universitas Bengkulu.

Suarmika, I. G. L., \& Suputra, I. D. G. D. (2016). Kemampuan Komitmen Organisasi dan Sistem Pengendalian Intern Memoderasi Pengaruh Kapasitas Sumber Daya Manusia dan Penerapan SIKD Pada Kualitas LKPD Kabupaten KarangAsem. E-Jurnal Ekonomi Dan Bisnis, Vol 5 No 9.

Sudiarianti, N. M., Ulupui, I. G. K. A., \& Budiasih, I. G. (2015). Pengaruh Kompetensi Sumber Daya Manusia Pada Penerapan Sistem Pengendalian Intern Pemerintah Dan Standar Akuntansi Pemerintah Serta Implikasinya Pada Kualitas Laporan Keuangan Pemerintah Daerah. E-Journal Akuntansi Universitas Udayana.

Sugiyono. (2017). Metode Penelitian Bisnis. Alfabeta.

Tambingon, H. N., Yadiati, W., \& Kewo, C. L. (2018). Determinant factors influencing the quality of financial reporting local government in Indonesia. International Journal of Economics and Financial Issues, Vol 24 No 1, Hal 768-792.

Trisnawati, N. N., \& Wiratmaja, D. N. (2018). Pengaruh Kualitas Sumber Daya Manusia dan Sistem Pengendalian Intern pada Kualitas Laporan Keuangan Pemerintah Daerah. EJurnal Akuntansi, Vol 24 No 1, Hal 768-792.

Wati, K. D., Herawati, N. T., \& Sinarwati, N. K. (2014). Pengaruh Kompetensi SDM, Penerapan 
SAP, dan Sistem Akuntansi Keuangan daerah Terhadap Kualitas Laporan Keuangan Daerah. E-Journal S1 AK Universitas Pendidikan Ganesha., Vol 2 No 1.

Widarsono, A \& Lediana, N. Y. (2013). Pengaruh Efektivitas Penerapan Teknologi Informasi Terhadap Kualitas Laporan Keuangan Pemerintah Daerah. Keuangan Universitas Pendidikan Indonesia, Vol 1 No 1. 